\title{
Prevalence of Neospora spp. in donkeys in China
}

\author{
Wei Cong ${ }^{1}$, Lan-Bi Nie ${ }^{2}$, Si-Yuan Qin ${ }^{3}$, Wei-Li Wang ${ }^{4}$, Ai-Dong Qian ${ }^{2}$, and Qing-Feng Meng ${ }^{2,4, *}$ \\ ${ }^{1}$ College of Marine Science, Shandong University at Weihai, Weihai, Shandong Province 264209, PR China \\ ${ }^{2}$ College of Animal Science and Technology, Jilin Agricultural University, Changchun, Jilin Province 130118, PR China \\ ${ }^{3}$ General Station for Surveillance of Wildlife Diseases \& Wildlife Borne Diseases, State Forestry Administration (SFA), \\ Shenyang 110034, PR China \\ 4 Jilin Entry-Exit Inspection and Quarantine Bureau, ChangChun, Jilin Province 130000, PR China
}

Received 13 January 2018, Accepted 6 March 2018, Published online 20 March 2018

\begin{abstract}
This study was conducted to detect specific anti-Neospora antibodies using a commercial competitive-inhibition ELISA kit, and to evaluate the risk factors for Neospora spp. infection. Out of a total of 2,228 donkey sera collected in three provinces in China, 211 (9.5\%) were found to be positive for anti-Neospora antibodies. Statistical analysis revealed that age $(p=0.019, \mathrm{OR}=1.62,95 \% \mathrm{CI}: 1.08-2.44)$, feeding status $(p<0.001, \mathrm{OR}=3.79,95 \% \mathrm{CI}: 2.65-5.43)$, miscarriage history $(p=0.006, \mathrm{OR}=2.56,95 \% \mathrm{CI}: 1.27-4.01)$, and contact with dogs $(p<0.001, \mathrm{OR}=2.69,95 \% \mathrm{CI}$ : 1.86-3.88) were significant risk factors for Neospora spp. infection. This is the first evidence of Neospora infection in donkeys in China.
\end{abstract}

Keywords: Neospora, cELISA, detection, donkeys, China

Résumé-Prévalence de Neospora spp. chez les ânes en Chine. Cette étude a été menée pour détecter les anticorps spécifiques anti-Neospora par un kit ELISA compétitif d'inhibition compétitive et évaluer les facteurs de risque des infections par Neospora spp. Sur un total de 2228 sérums d'ânes collectés dans trois provinces de Chine, $211(9,5 \%)$ ont été trouvés positifs pour les anticorps anti-Neospora. L'analyse statistique a révélé que l'âge ( $p=0,019, \mathrm{OR}=1,62$, IC à $95 \%: 1,08-2,44)$, l'alimentation $(p<0,001, \mathrm{OR}=3,79, \mathrm{IC}$ à $95 \%: 2,65-5,43)$, l'historique d'avortements ( $p=0,006, \mathrm{OR}=2,56$, IC à $95 \%: 1,27-4,01)$, et le contact avec les chiens $(p<0,001$, $\mathrm{OR}=2,69$, IC à $95 \%: 1,86-3,88)$ étaient des facteurs de risque significatifs pour l'infection à Neospora spp. Ceci est la première preuve d'infection à Neospora chez les ânes en Chine.

\section{Introduction}

Neospora spp. are globally distributed obligate intracellular parasites [22] and are closely related to Toxoplasma gondii and Sarcocystis spp., belonging to the phylum Apicomplexa of the Sarcocystidae family [7]. Neospora can infect a wide variety of hosts [8]. Dogs, coyotes and dingoes are definitive hosts of Neospora spp. $[13,14,19]$, and certain other mammal species, including cattle and other ruminants, canids and horses can serve as intermediate hosts [10].

Equine neosporosis caused by two species of Neospora (Neospora caninum and Neospora hughesi), is accompanied by neurologic symptoms and reproductive loss $[9,21]$. Donkeys (Equus asinus) are closely related to horses and can be infected by some equine pathogens such as the

\footnotetext{
*Corresponding author: mqfboy@163.com
}

protozoa Theileria equi and Babesia caballi [18]. Seroprevalences of Neospora spp. in donkeys have only been reported from Southern Italy [17], Nigeria [5], Brazil [11] and Mexico [1]. However, until now, no information was available about the prevalence of this protozoal disease in donkeys from China. Thus, the aim of this study was to detect antibodies to Neospora ssp. in donkeys from three provinces in China, and to evaluate the risk factors associated with Neospora seroprevalence.

\section{Materials and methods}

Serum samples were randomly collected from the jugular vein of 2,228 donkeys from Shandong province $\left(4^{\circ} 23^{\prime} \sim 38^{\circ} 24^{\prime} \mathrm{N}, 114^{\circ} 48^{\prime} \sim 122^{\circ} 42^{\prime} \mathrm{E}\right)$, Henan province $\left(31^{\circ} 23^{\prime} \sim 36^{\circ} 22^{\prime} \mathrm{N}, 110^{\circ} 21^{\prime} \sim 116^{\circ} 39^{\prime} \mathrm{E}\right)$, and Hebei province $\left(36^{\circ} 05^{\prime} \sim 42^{\circ} 40^{\prime} \mathrm{N}, 113^{\circ} 27^{\prime} \sim 119^{\circ} 50^{\prime} \mathrm{E}\right)$ between November 2015 and June 2017 by local veterinary practitioners 


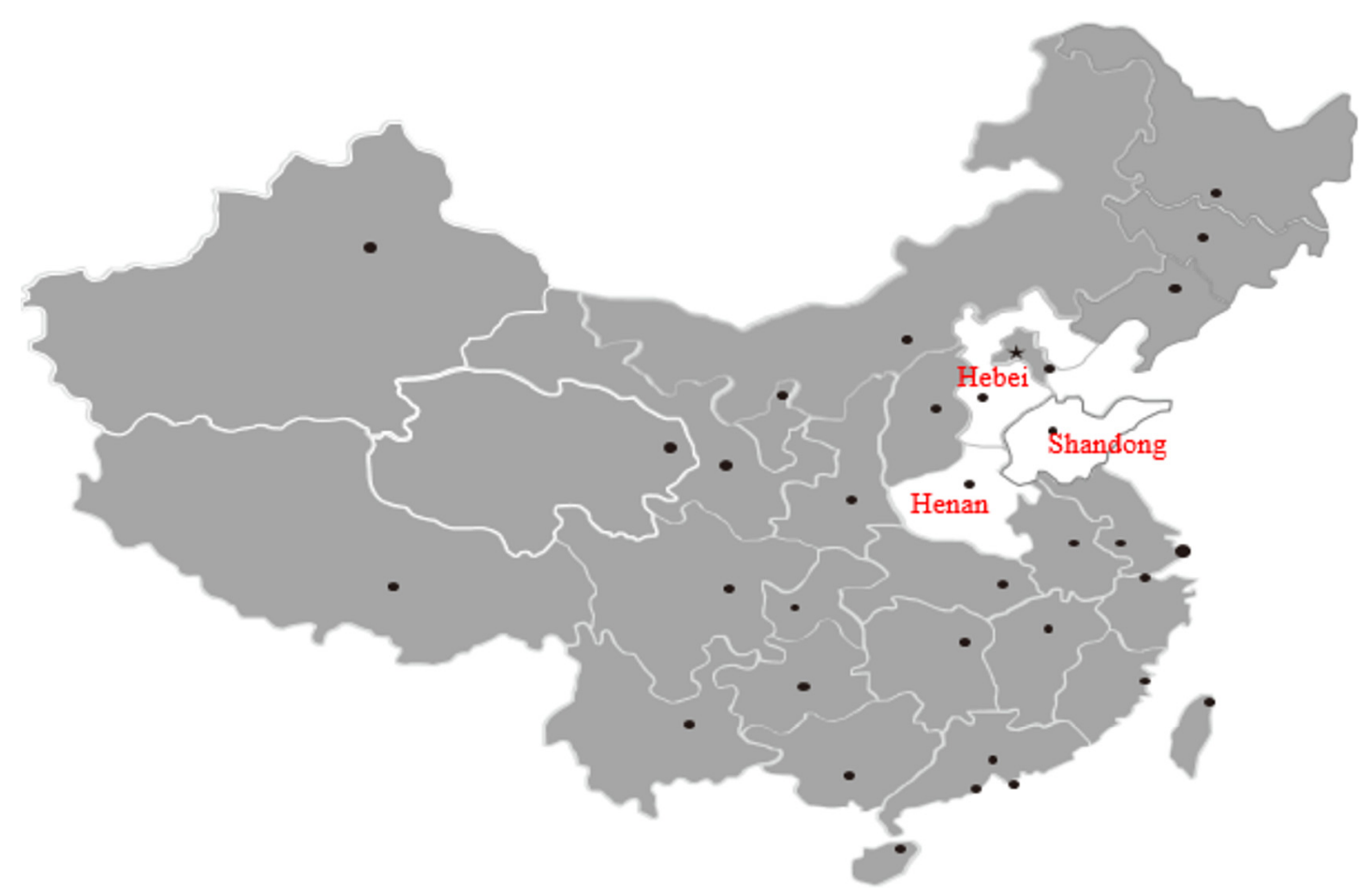

Figure 1. Map of China showing the geographical regions of Hebei, Henan and Shandong provinces where donkeys were sampled.

(Figure 1). Donkeys from each farm were selected randomly using a table of random digits. Several large-scale farms (with more than 300 animals) were not included because the owner did not authorize us to collect samples. Approximately $30 \%$ donkeys at each farm were sampled. All of the animals sampled were clinically healthy. Serum samples from backyard donkeys were randomly collected when authorization was obtained from the owners of the donkeys. Serum was obtained through centrifugation at $3000 \times g$ for $5 \mathrm{~min}$ and stored at $-20^{\circ} \mathrm{C}$ until tested. Information about breeds, gender, age, contact with dogs, miscarriage history, and feeding status was acquired from the owners.

A commercial competitive-inhibition enzyme-linked immunosorbent assay kit (cELISA) (VMRD, Pullman, WA, USA) was used to detect Neospora antibodies, according to the manufacturer's instructions [17]. The serum was tested in duplicate and considered positive when the percent inhibition values of both runs were more than $30 \%$.

For the statistical analysis, the SPSS 18.0 software package (IBM, Armonk, NY, USA) was used. The Fisher exact test was used to compare the frequencies among groups. Bivariate and multivariate logistic analyses were used to assess the association between the characteristics of the subjects and the Neospora infection. Variables were included in the multivariate logistic analysis if they had a $p$ value of equal to or less than 0.35 in the bivariate logistic analysis [1]. A $p$ value less than 0.05 was considered statistically significant. Odds-ratios (ORs) with 95\% confidence intervals based on likelihood ratio statistics were calculated.

This study was approved by the Animal Ethics Committee of Jilin Agricultural University. Serum samples were collected and handled in accordance with the requirements of the Animal Ethics Procedures and Guidelines of the People's Republic of China.

\section{Results and discussion}

Commercial competitive-inhibition ELISA kits have been used widely to detect Neospora antibodies in many kinds of animals including donkeys [17] due to the method's high accuracy, sensitivity and accessibility [4]. We therefore first used this method to assess the serologic frequency of antibodies to Neospora in donkeys from China. Out of a total of 2,228 donkeys, 211 (9.5\%) were found to be positive for Neospora antibodies. General data for the 2,228donkeys studied and seroprevalence of Neospora spp. infection are shown in Table 1.

In the present study, age of donkeys was a significant risk factor for this parasitic infection, on the basis of multivariate logistic analysis. The donkeys in age categories $\leq 1$ year $(p=0.019, \mathrm{OR}=1.62,95 \% \mathrm{CI}: 1.08-2.44)$ were found to have a significantly higher seroprevalence than the other age groups, suggesting that donkeys were exposed to the parasite infection at the early stages of their lives. The same phenomenon was found in a previous 
Table 1. General data for the 2,228 donkeys studied and seroprevalence of Neospora spp. infection.

\begin{tabular}{|c|c|c|c|c|c|}
\hline Variable & Category & No. tested & No. positive & Prevalence $(\%)$ & $p$-value \\
\hline \multirow[t]{3}{*}{ Breed } & Dezhou & 1125 & 111 & 9.9 & 0.383 \\
\hline & Wutou & 756 & 63 & 8.3 & \\
\hline & Sanfen & 347 & 37 & 10.7 & \\
\hline \multirow[t]{3}{*}{ Age } & $\leq 1$ year & 466 & 57 & 12.2 & 0.073 \\
\hline & 1-5 year & 1047 & 92 & 8.8 & \\
\hline & $\geq 5$ year & 715 & 62 & 8.7 & \\
\hline \multirow[t]{2}{*}{ Gender } & Male & 1181 & 104 & 8.8 & 0.255 \\
\hline & Female & 1047 & 107 & 10.2 & \\
\hline \multirow[t]{3}{*}{ Province } & Shandong & 847 & 84 & 9.9 & 0.824 \\
\hline & Hebei & 626 & 59 & 9.4 & \\
\hline & Henan & 755 & 68 & 9.0 & \\
\hline \multirow[t]{2}{*}{ Feeding status } & Backyard & 235 & 68 & 28.9 & $<0.001$ \\
\hline & Farm & 1993 & 143 & 7.2 & \\
\hline \multirow[t]{3}{*}{ Sampling year } & 2015 & 615 & 59 & 9.6 & 0.919 \\
\hline & 2016 & 1027 & 99 & 9.6 & \\
\hline & 2017 & 586 & 53 & 9.0 & \\
\hline \multirow[t]{4}{*}{ Season } & Spring & 304 & 24 & 7.9 & 0.578 \\
\hline & Summer & 639 & 61 & 9.5 & \\
\hline & Autumn & 724 & 66 & 9.1 & \\
\hline & Winter & 561 & 60 & 10.7 & \\
\hline \multirow[t]{2}{*}{ Miscarriage history } & Yes & 112 & 20 & 17.9 & 0.002 \\
\hline & No & 2116 & 191 & 9.0 & \\
\hline \multirow[t]{2}{*}{ Contact with dogs } & Yes & 246 & 62 & 25.2 & $<0.001$ \\
\hline & No & 1982 & 149 & 7.5 & \\
\hline Total & & 2228 & 211 & 9.5 & \\
\hline
\end{tabular}

study [17]. Moreover, maternal antibodies may have been ingested by colostrum, which may give positive results. This is because the variable is $<1$ year, which could include a few months of life and thereby influence the result. Interestingly, nine female donkeys and their offspring were found to be positive for Neospora antibodies. This phenomenon leads us to consider possible vertical transmission of Neospora infection in donkeys in further studies.

Neospora infection can induce clinical neosporosis disease, which notably presents as abortion in ruminants. Worldwide, these abortions are the main reason for economic loss to both the dairy and beef industries $[6,15]$. In the present study, the result of multivariate logistic analysis showed that donkeys with a history of miscarriages have a significantly higher Neospora seroprevalence than those without $(p=0.006$, OR $=$ 2.56, 95\% CI: 1.27-4.01). Although no direct evidence showed that the miscarriages of donkeys were caused by Neospora infection, prevention and control of Neospora infection should be carried out in the process of raising donkeys. Moreover, further studies should be conducted to explore the association between miscarriage and Neospora infection.
Dogs, the definitive hosts of Neospora, play an important role in the transmission of $N$. caninum, discharging oocysts into the environment [16,20,22], which is a main risk factor for the occurrence of miscarriages and stillbirths associated with $N$. caninum in ruminants and other intermediate hosts $[2,3,12]$. Not surprisingly, the donkeys have a significantly higher seroprevalence when they have contact with dogs compared to those without contact $(p<0.001, \mathrm{OR}=$ 2.69, 95\% CI: 1.86-3.88). In China, dogs often act as guard animals on farms, so this may increase the possibility of $N$. caninum infection. Thus, more protective measures should be implemented to reduce $N$. caninum infection in donkeys, such driving stray dogs from the farms, etc.

In the present study, backyard donkeys had a significantly higher seroprevalence than those feeding on farms $(p<0.001, \mathrm{OR}=3.79,95 \% \mathrm{CI}: 2.65-5.43)$. The most likely explanation is that donkeys feeding in backyards have greater contact with dogs because many dogs are raised in the owner's home as guard animals. However, all farms were positive for the presence of Neospora antibodies. It is therefore impossible to evaluate the role of farms as a risk factor. Further studies should be conducted to explore the 
role played by neosporosis in reproductive and economic losses to donkey breeding in these regions.

\section{Conclusions}

This is the first report of Neospora seroprevalence and risk factors associated with Neospora infection in donkeys from China, providing baseline data for designing and evaluating prevention and control measures. More studies are needed to understand and evaluate the occurrence of transplacental transmission throughout pregnancy. Similarly, the occurrence of neurological diseases or fetal loss in the life of congenitally infected donkeys should also be investigated.

Acknowledgments. This work was supported by grants from the National Key R\&D Program of China (2017YFD0501000).

\section{Conflict of interest}

The authors declare that they have no conflicts of interest in relation to this article.

\section{References}

1. Alvarado-Esquivel C, Howe DK, Yeargan MR, AlvaradoEsquivel D, Alfredo Zamarripa-Barboza J, Dubey JP. 2017. Seroepidemiology of Sarcocystis neurona and Neospora hughesi infections in domestic donkeys (Equus asinus) in Durango, Mexico. Parasite, 24, 27.

2. Arunvipas P, Inpankaew T, Jittapalapong S. 2012. Risk factors of Neospora caninum infection in dogs and cats in dairy farms in Western Thailand. Tropical Animal Health and Production, 44, 1117-1121.

3. Asadpour R, Jafari-Joozani R, Salehi N. 2013. Detection of Neospora caninum in ovine abortion in Iran. Journal of Parasitic Diseases, 37, 105-109.

4. Bártová E, Kobédová K, Lamka J, Kotrba R, Vodička R, Sedlák K. 2017. Seroprevalence of Neospora caninum and Toxoplasma gondii in exotic ruminants and camelids in the Czech Republic. Parasitology Research, 116, 1925-1929.

5. Bártová E, Sedlák K, Kobédová K, Budíková M, Joel Atuman Y, Kamani J. 2017. Seroprevalence and risk factors of Neospora spp. and Toxoplasma gondii infections among horses and donkeys in Nigeria, West Africa. Acta Parasitologica, 62, 606-609.

6. Basso W, Moré G, Quiroga MA, Balducchi D, Schares G, Venturini MC. 2014. Neospora caninum is a cause of perinatal mortality in axis deer (Axis axis). Veterinary Parasitology, 199, 255-258.

7. Cazarotto CJ, Balzan A, Grosskopf RK, Boito JP, Portella LP, Vogel FF, Fávero JF, de C Cucco D, Biazus AH, Machado G, Da Silva AS. 2016. Horses seropositive for
Toxoplasma gondii, Sarcocystis spp. and Neospora spp.: Possible risk factors for infection in Brazil. Microbial Pathogenesis, 99, 30-35.

8. Dubey JP. 2003. Review of Neospora caninum and neosporosis in animals. Korean Journal of Parasitology, 41, 1-16.

9. Dubey JP, Porterfield ML, 1990. Neospora caninum (Apicomplexa) in an aborted equine fetus. Journal of Parasitology, 76, 732-734.

10. Dubey JP, Schares G, Ortega-Mora LM. 2007. Epidemiology and control of neosporosis and Neospora caninum. Clinical Microbiology Reviews, 20, 323-367.

11. Galvão CM, Rezende-Gondim MM, Chaves AC, Schares G, Ribas JR, Gondim LF. 2015. Brazilian donkeys (Equus asinus) have a low exposure to Neospora spp. Brazilian Journal of Veterinary Parasitolog, 24, 340-344.

12. Ghalmi F, China B, Kaidi R, Losson B. 2011. Neospora caninum is associated with abortion in Algerian cattle. Journal of Parasitology, 97, 1121-1124.

13. Gondim LF, McAllister MM, Pitt WC, Zemlicka DE. 2004. Coyotes (Canis latrans) are definitive hosts of Neospora caninum. International Journal for Parasitology, 34, 159-161.

14. King JS, Slapeta J, Jenkins DJ, Al-Qassab SE, Ellis JT, Windsor PA. 2010. Australian dingoes are definitive hosts of Neospora caninum. International Journal for Parasitology, 40, 945-950.

15. Larson RL, Hardin DK, Pierce VL. 2004. Economic considerations for diagnostic and control options for $\mathrm{NeO}$ spora caninum-induced abortions in endemically infected herds of beef cattle. Journal of the American Veterinary Medical Association, 224, 1597-1604.

16. Lindsay DS, Dubey JP, Duncan RB. 1999. Confirmation that the dog is a definitive host for Neospora caninum. Veterinary Parasitology, 82, 327-333.

17. Machačová T, Bártová E, Di Loria A, Sedlák K, Guccione J, Fulgione D, Veneziano V. 2013. Seroprevalence and risk factors of Neospora spp. in donkeys from Southern Italy. Veterinary Parasitology, 198, 201-204.

18. Machado RZ, Toledo CZP, Teixeira MCA, André MR, Freschi CR, Sampaio PH. 2012. Molecular and serological detection of Theileria equi and Babesia caballi in donkeys (Equus asinus) in Brazil. Veterinary Parasitology, 186, 461-465.

19. McAllister MM, Dubey JP, Lindsay DS, Jolley WR, Wills RA, McGuire AM. 1998. Dogs are definitive hosts of Neospora caninum. International Journal for Parasitology, 28, 1473-1478.

20. Nazir MM, Maqbool A, Akhtar M, Ayaz M, Ahmad AN, Ashraf K, Ali A, Alam MA, Ali MA, Khalid AR, Lindsay DS. 2014. Neospora caninum prevalence in dogs raised under different living conditions. Veterinary Parasitology, 204, 364-368.

21. Pitel PH, Romand S, Pronost S, Foucher N, Gargala G, Maillard K, Thulliez P, Collobert-Laugier C, Tainturier D, Fortier G, Ballet JJ. 2003. Investigation of Neospora sp. antibodies in aborted mares from Normandy, France. Veterinary Parasitology, 118, 1-6.

22. Wang S, Yao Z, Zhang N, Wang D, Ma J, Liu S, Zheng B, Zhang B, Liu K, Zhang H. 2016. Serological study of Neospora caninum infection in dogs in central China. Parasite, 23, 25. 
O PARASTE

An international open-access, peer-reviewed, online journal publishing high quality papers on all aspects of human and animal parasitology

Reviews, articles and short notes may be submitted. Fields include, but are not limited to: general, medical and veterinary parasitology; morphology, including ultrastructure; parasite systematics, including entomology, acarology, helminthology and protistology, and molecular analyses; molecular biology and biochemistry; immunology of parasitic diseases; host-parasite relationships; ecology and life history of parasites; epidemiology; therapeutics; new diagnostic tools.

All papers in Parasite are published in English. Manuscripts should have a broad interest and must not have been published or submitted elsewhere. No limit is imposed on the length of manuscripts.

Parasite (open-access) continues Parasite (print and online editions, 1994-2012) and Annales de Parasitologie Humaine et Comparée (1923-1993) and is the official journal of the Société Française de Parasitologie. 